\title{
材料リスク情報プラットフォームメインシステムの 開発計画
}

\section{野邊 潤 辻 禎之 丸貴徹庸寺邊正大}

\author{
株式会社 三菱総合研究所
}

J. Japan Inst. Metals, Vol. 66, No. 12 (2002), pp. 1271-1277 Special Issue on Materials and Technologies for Risk Society (C) 2002 The Japan Institute of Metals Overview

\section{Project Plan of Main System of the Material Risk Information Platform}

Jun Nobe, Yoshiyuki Tsuji, Tetsu Maruki and Masahiro Terabe

Mitsubishi Research Institute, Inc., Tokyo 100-8141

"Risk-based design", "risk-based manufacturing", and "risk-based maintenance" are increasingly being applied to the area of mechanical equipment. These are very useful concepts and methods for plant management, etc.; however, when the risks associated with mechanical equipment are examined from the viewpoint of materials, it is often difficult to obtain risk information for use as a basis for study. One reason is that most materials-related databases tend to be built separately for individual fields of study, and are limited to digitized numerical data. As an approach to solving this problem, our team began in the middle of 2001 an investigation of the feasibility of setting up a platform system for material risk information. This project was cooperated in and supported by the National Institute for Material Science. The concept of this system is a portal site to be used via the Internet, designed to collect information related to material risk from a distributed network environment and to provide it to users. "Life test data on materials", "information on problems or accidents attributable to materials", "standard information", "information related to various evaluations", "other risk information" etc., comprise the material risk information used. This paper gives an overview of our platform system for collecting information on materials-related risks and the overall project plan.

(Received August 27, 2002; Accepted September 30, 2002)

Keywords: material risk, platform system, portal site, distributed network environment, web service, metadata

\section{1. 緒言}

昨今，機械設備においてリスクベース設計，リスクベース マニュファクチャリング，リスクベースメインテナンスとい う考え方や手法が聞かれるようになった1)。これらの考え方 が注目される理由としては，現代社会において使用される機 械設備の曝される環境が非常に多岐に渡ることにより，特定 の基準や規則によって設計，製造，管理することが必ずしも 合理的でないことが分かってきたためと考えられる22.これ は多くの経験とデータの蓄積によっても裏付けられている. また社会的に見ると，規制緩和や自己責任という概念のも と，競争市場で生き抜くためにいかにコストとメリットをバ ランスさせるかというシビアな問題もリスクベースの考え方 に注目が集まる背景にある。

しかし，材料の視点から機械設備のリスクを捉えようとし た場合，その基盤となるリスク情報の入手は容易ではない. これは，首藤等が指摘しているように現在ある材料関係の データベースのほとんどが専門分野ごとに独立して構築さ れ，電子化された数值ファクトデータにとどまっていること に一因がある3)。また，それらをリスクベースで捉える場合
に必要となるバラツキや確率に関する情報の不足なども原因 と言える。

そこで，物質・材料研究機構が中核機関となり，2001年 半ばより，材料リスク情報プラットフォームシステム (以 下，本システム)の検討ならびに開発プロジェクト（以下，本 プロジェクト)を開始した ${ }^{4)}$. 本プロジェクトでは，開発当 初のターゲットとして火力発電プラントにおけるボイラ回り の金属材料を中心に据えている，また，本システムは，イン ターネットでの利用を前提としたポータルサイトであり，分 散ネットワーク環境に散在する材料のリスクに関する情報を 有機的に繋げて材料リスク情報として提供することを目指す ものである．材料リスク情報としては,「材料の寿命試験デー 夕」「材料に起因する事故情報」「規格 ·基準の情報」「各種 評価関連情報」「その他のリスク情報」等を想定している. 本プラットフォームにより, リスクの視点を持った者が独自 に情報収集していた従来の状況が改善され，少ない労力で材 料リスク情報が入手できるようになる.

本報告では，材料のリスクに係わる情報を収録しインター ネットで提供する本プラットフォームのメインシステムの機 能を説明すると共に，仕様構想を報告する. 
Table 1 Example of risk information focusing on material.

\begin{tabular}{lll}
\hline \multicolumn{1}{c}{ Application } & Required function & Example of loss of function \\
\hline Structural material & $\begin{array}{l}\text { - Bearing a static } \\
\text { load } \\
\text { Bearing a dynamic } \\
\text { load }\end{array}$ & $\begin{array}{l}\text { Ductile fracture, Brittle frac- } \\
\text { ture, Fatigue } \text { etc. }\end{array}$ \\
\hline Pressure vessel & $\begin{array}{l}\text { - Bearing an internal } \\
\text { pressure }\end{array}$ & $\begin{array}{l}\text { Ductile fracture, Brittle frac- } \\
\text { ture, Creep, Stress corrosion } \\
\text { cracking, etc. }\end{array}$ \\
\hline Pipe & - Prevention of leak & Corrosion, etc. \\
\hline Radioactive shield & - Shields of radiation & Deterioration, Thinning, etc. \\
\hline
\end{tabular}

\section{2. 材料リスク情報とは}

2002 年に発行された ISO / IEC Guide 73 ではリスク (Risk) "combination of the probability of an event and its consequence” と定義している。この定義に示されるよう に，一般にリスクは「発生確率(または頻度)」と「その結果 (被害)」で表現される。この場合の被害としては，金銭的な 損失や人命の損失，物的な被害などを対象にすることが多 い、しかし「材料リスク情報」と言った場合に，材料だけを 特定してもどのような被害が発生するか特定できないことが ほとんどである。つまりどのような環境やどのような機器, またはシステムに扔いてそれらの材料が使用されるか決まら ないと，その被害形態の発生確率は見積れない。

そこで，材料を中心にリスクという体系を見直してみる. 材料単体(ステンレス鋼の板やコンクリートの塊)が存在する だけでは, リスクの同定は困難であることは先に述べた通り である.もう一歩進めて, 材料の利用状況まで考慮してみ る. 例えば, 材料が建造物の柱や高圧ガスの圧力容器に用い られる状況を考える.この場合，材料には建造物の荷重を支 える機能であるとかガス圧に耐える機能が求められているこ とがわかる．この機能を失うことは材料を中心に考えた場合 のリスクと言えないであろうか.つまり，材料の用途が決ま った段階で既にその材料に求められた機能があり，その機能 が失われること自体が損失であり，その発生がどのような確 率で起るかということを材料に関するリスクとして捉えるこ とができるのでは無いかと考える．この考え方に基づくと， 材料リスク情報とは材料に求められる機能を喪失する事象に 関する情報と言える．材料を出発点とした機能衰失の例とそ の関連情報例を Table 1 に示す。なお， Table 1 に示したよ うな機能喪失の要件は一般的なリスクの八ザードに相当する と考えられる.

本システムではこの概念のもとに材料リスクに関連する情 報を位置付け，開発するものとした。

\section{3. 材料リスク情報プラットフォームとは}

本システムは「材料リスク情報プラットフォームシステム」 と名付けられている．情報システム系の分野では，「プラッ トフォーム」を，アプリケーションソフトに対するハードお よびオペレーティングシステムを総称したコンピュータシス テム自体として用いることがあるが，最近はかなり広い意味
Table 2 Concept of the platform system.

(1) The base system which can widely provide the information relevant to material risk.

(2) The open system which can add the various tools relevant to material risk.

(3) The standard system which can link with other tools and information system relevant to material risk.

で用いられる. 小野等は，「情報プラットフォーム」の概念 を「情報を集めて組織化するところ(収集・構築)，保存して 抢くところ(蓄積)，流通するところ(流通)，情報を取り出し 利用するところ(利用) となる共通基盤」と見なしている5. 本システムで言う「プラットフォーム」とは, 概念的に単な るコンピュータシステムではなく, 小野等の定義に近いもの である. 具体的には Table 2 に示す要素を満たすシステムと 位置付けられるものである.

本システムに打けるプラットフォーム機能とは同じプラッ トフォームという用語を用いる鉄道に打ける八ブ的な中央駅 と捉えると理解しやすい，ハブ的な中央駅においては重要な 列車の発着場所として, 基盤的な位置付けがある. 目的とな る情報へのスタート地点や情報獲得のための乗り継ぎ地点と いうイメージであり, Table 2 の11に相当する. また，ハブ 的な中央駅に抢いては基盤という位置付けだけで無く，その 空間を利用して宿泊案内や嗜好品の販売など椂々なサービス の提供がなされる場所でもある．これは，本システムを利用 して新たなサービスが展開されることを可能にすることに相 当する.これが Table 2 に扔ける(2)のオープンなシステムに 相当する. さらに, 他の鉄道会社の列車と乗り入れが可能で あれば，その駅の利用者には遠くまで旅する可能性を提供す るが，そのためには線路等の共通規格を使う必要がある。こ れは Table 2 に打ける(3)のスタンダードなシステムに相当す る.

\section{4. 本システムの機能}

本システムの特徵は, 先述のように材料を中心にリスクを 捉え，それらに関する情報をプラットフォームという概念の もとにシステム化することにある. システム化にあたっての 機能の柱は以下の三つに集約される.

・材料リスク情報に関するポータル機能

・材料リスク情報と WEB サービスの追加機能

・材料リスク評価情報の提示機能

以下に各機能の内容を示す.

\section{1 材料リスク情報に関するポータル機能}

本システムの第一の機能としては, インターネットにおけ るポータルサイトに相当する機能を基礎として, その機能を 高めたものである.

本システムに抢けるポータル機能のイメージを Fig. 1 に 示す. 本システムに扔けるポータル機能とは, あらゆるジャ ンルを検索対象にしたようなシステムとは異なり，材料リス ク情報に特化したものである. Fig. 1 では材料リスクに関連 する情報を 6 つに分類し, 材料を起点としてそれらの情報 


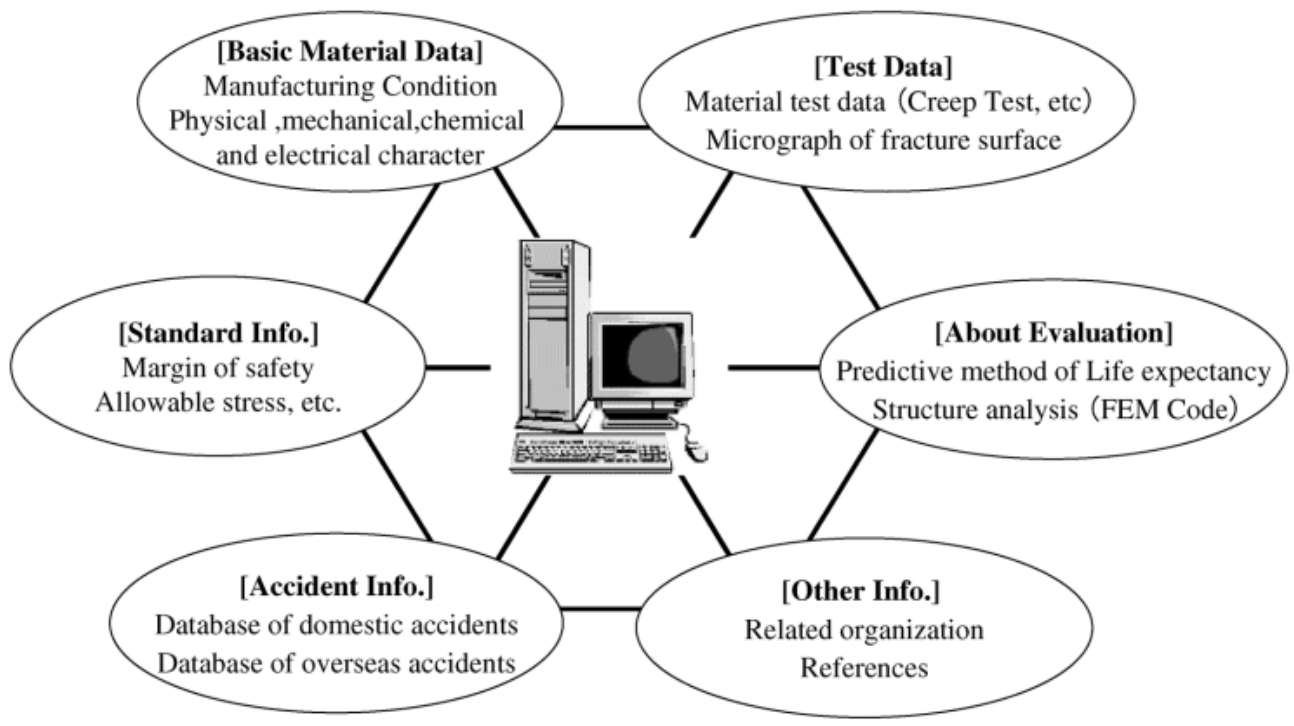

Fig. 1 Image of portal function of this system.

Table 3 The portal function of material risk information.

\begin{tabular}{|c|c|c|}
\hline Group & Content & Examples \\
\hline $\begin{array}{l}\text { Basic material } \\
\text { data }\end{array}$ & $\begin{array}{l}\text { Characteristic data about } \\
\text { the material, which is need- } \\
\text { ed to grasp the risk resulting } \\
\text { form materials. }\end{array}$ & $\begin{array}{l}\text { - Manufacturing condi- } \\
\text { tion } \\
\text { - Physical, mechanical, } \\
\text { chemical and electri- } \\
\text { cal character }\end{array}$ \\
\hline Material test data & $\begin{array}{l}\text { The information containing } \\
\text { raw data about the test to } \\
\text { functional loss of material. } \\
\text { Moreover, research data } \\
\text { about the result of function- } \\
\text { al loss material. }\end{array}$ & $\begin{array}{l}\text { - Data of Creep Test } \\
\text { - Micrograph of frac- } \\
\text { ture surface }\end{array}$ \\
\hline $\begin{array}{l}\text { Standard infor- } \\
\text { mation }\end{array}$ & $\begin{array}{l}\text { Various kinds of specifica- } \\
\text { tion or safe standards, which } \\
\text { are consulted when design- } \\
\text { ing using material }\end{array}$ & $\begin{array}{l}\text { - Margin of safety } \\
\text { - Allowable stress }\end{array}$ \\
\hline About evaluation & $\begin{array}{l}\text { Present function of new in- } \\
\text { formation what utilizes char- } \\
\text { acteristic data about materi- } \\
\text { als and various kinds of } \\
\text { knowledge bases. }\end{array}$ & $\begin{array}{l}\text { - Predictive method of } \\
\text { Life expectancy } \\
\text { - Structure analysis } \\
\text { system }\end{array}$ \\
\hline $\begin{array}{l}\text { Accident informa- } \\
\text { tion }\end{array}$ & $\begin{array}{l}\text { Database of accident or } \\
\text { trouble information result- } \\
\text { ing from material }\end{array}$ & $\begin{array}{l}\text { - Domestic accidents } \\
\text { - Overseas accidents }\end{array}$ \\
\hline Other information & $\begin{array}{l}\text { Other Useful information as } \\
\text { material risk information }\end{array}$ & $\begin{array}{l}\text { - Related organization } \\
\text { - References }\end{array}$ \\
\hline
\end{tabular}

源にたどり着くことができることを示している.

材料リスクに関連する情報間の材料リスク情報の区分を Table 3 に示す。 なお, 実際に格納される情報は単一の情報 区分にのみ属するとは限らず，複数の区分に属するものもあ りえると考える.

また，本システムは単一のサーバーだけで閉じるものでは 無く，インターネット上にある材料リスク情報に資する各種 のサーバーと分散協調できるシステムである.

\section{2 材料リスク情報と WEB サービスの追加機能}

材料リスク情報と WEB サービスの追加機能を実現するこ とは，本システムが将来に渡り，情報を追加可能で拡張可能 なインターフェイスを提供することを意味する. そのために は，新たなサービス追加や情報提供をする際に，情報提供側
もプラットフォームのメインサーバー側も極力省力化し，融 合できることが望ましい，そのような課題をクリアするシス テム構築の方向としては以下の二つの視点が重要となると考 える.

・統一されたアーキテクチャによるシステム構築

・標準化された規格の下でのシステム構築

前者は，プラットフォームに接続可能な仕様を予め決めて， その仕様に従ってメインサーバーを構築すると共に，その アーキテクチャの仕様を公開することによって，相互の接続 を可能にするものである，サービスを提供する他のサーバー においては，本アーキテクチャを参照してシステムを構築す れば，本システムと融合可能となる，後者は，先に示した アーキテクチャ自身に扔いて，標準的な技術を用いてシステ ム構築するものである。標準を採用することは，物理的なネ ットワークレベルからサービス提供のアプリケーションソフ トの中身に至るレベルまで，全ての階層に扔いて独自にアー キテクチャを定義する膨大な作業を大幅に削減する。さら に，サービスを提供する側にとっても，基本的な部分は一般 的な標準に準拠すればよく，材料リスク情報に特有な部分に のみ注力して開発することが可能になり双方のメリットがあ る.

以下にここに示した二つの視点を取り込んだアーキテクチ ヤの仕様構想を示す.

\subsubsection{WEB サービスに関するメタ情報の記述と登録}

本システムに抢いて，プラットフォームを構成する分散さ れた WEB サービスが相互に利用し，円滑に新しいWEB サービスが提供されるためには，各 WEB サービスに関する 情報を統一的に管理する仕組みが必要である。これは，材料 リスク情報プラットフォームの各種サーバーにおけるメタ情 報を定義し，登録管理することになる。ここで言うメタ情報 とは WEB サービス内容自身を記述した情報である.

メタ情報を構成するメタデータとしては，多様なメタデー タを扱うためのコンテナ・アーキテクチャとして提案された Warwick Frameworkに拮て“internally-referenced meta- 
data”と“externally-referenced metadata”があるとされて いる6 。前者はコンテンツの作者自身または管理者がコンテ ンツの一部またはコンテンツから参照されるように記述した ものであり, 後者はコンテンツ作者や管理者とは別の管理者 によって作成されるものを示している，本システムに䋆いて は，単なるデータ提供に留まらず，リスク評価に関する WEB アプリケーションシステムでもあることから，外部の 第三者が正確なメタ情報を作成することは困難と思われる. 従って, 本システムに抢いて共通となる仕様を定め, 各サ一 バーがその仕様に準拠してメタ情報を定義することが現実的 である，さらに，この定義された情報を各 WEB サービス サーバーや本システムの利用者が参照できるように登録管理 されていることが望をしい.

\subsubsection{UDDI および WSDL による基盤アーキテクチャ}

メタ情報を定義すると共に WEB サービスの中核を担う アーキテクチャとして, UDDI(Universal Description, Discovery and Integration) と WSDL (Web Service Description Language) が着目されている. UDDI ならびにWSDL は 2000 年半ばから提示された規格であるが，主要ベンダーが 中心になり次世代の WEB サービスの標準技術になると見ら れているものである7). 本システムでは, 相互参照および情 報登録の為の基盤アーキテクチャとして, UDDI および WSDL に準拠することを念頭においている.

UDDI を採用することによって，本システムで提供される サービスの内容やそのアクセス先について，決まった形式で 登録保持されることになる。この情報はメインサーバーにお いて管理される。 またWSDLは，サービス提供側によって 提示されるものであるが，自己のサービスの内容(提供場 所, アクセスインターフェイス, 実行方法等)を定義するも ので，換言すればサービス提供する情報自体のメタ情報につ
いての形式の統一である。

なお，UDDI ならびに WSDL に準拠した WEB サービス を採用することは，メインサーバーとサービス提供サーバー (メインサーバー自身も含む)の間での通信プロトコルとデー タ形式についても標準が存在する。そもそもUDDI および WSDL はXML(Extensible Markup Language)形式で記述 される. 従って, メタ情報の通信にはXMLをべースにした 通信プロトコルである SOAP(Simple Object Access Protocol)が採用される. XML は既に WEB サービスの中心的 なデータ記述形式として地位を確立しているが，その XML データをSOAP によって通信することで, ユーザーは通信 プロトコルの詳細な記述から開放される.

\subsection{3 本システムにおける UDDI, WSDL の利用イメージ}

本システムをUDDI および WSDL に準拠して開発した場 合の，基本的な利用例と応用的な利用例を以下に示す.

\section{（1） UDDI と WSDL の基本的な利用例}

UDDI とWSDL の基本的な利用例を Fig. 2 に示す. Fig. 2 では, 本システムの情報提供内容を一括管理するサービス ブローカ (以下 SB) としてメインサーバーを相当させてい る.さらに, 本システムとして情報提供したいサーバー(群) をサービスプロバイダ(以下 SP) とし, 実際にサービスを利 用したいユーザーの端末をサービスリクエスタ (以下 SR) と 位置付けている.

第一ステップとして SP は SOAP を利用して SB にサービ ス内容を登録している。この情報が UDDI として管理され る. 第二ステップでは, SR であるユーザーがメインサー バーからなんらかの材料リスク情報を取得しようとアクセス し，サービス内容を検索する．第三ステップとして，SR は $\mathrm{SB}$ から提示された情報により SP にアクセスし, クライア ントはSPのサービスを利用する. 以上が基本的な UDDI と

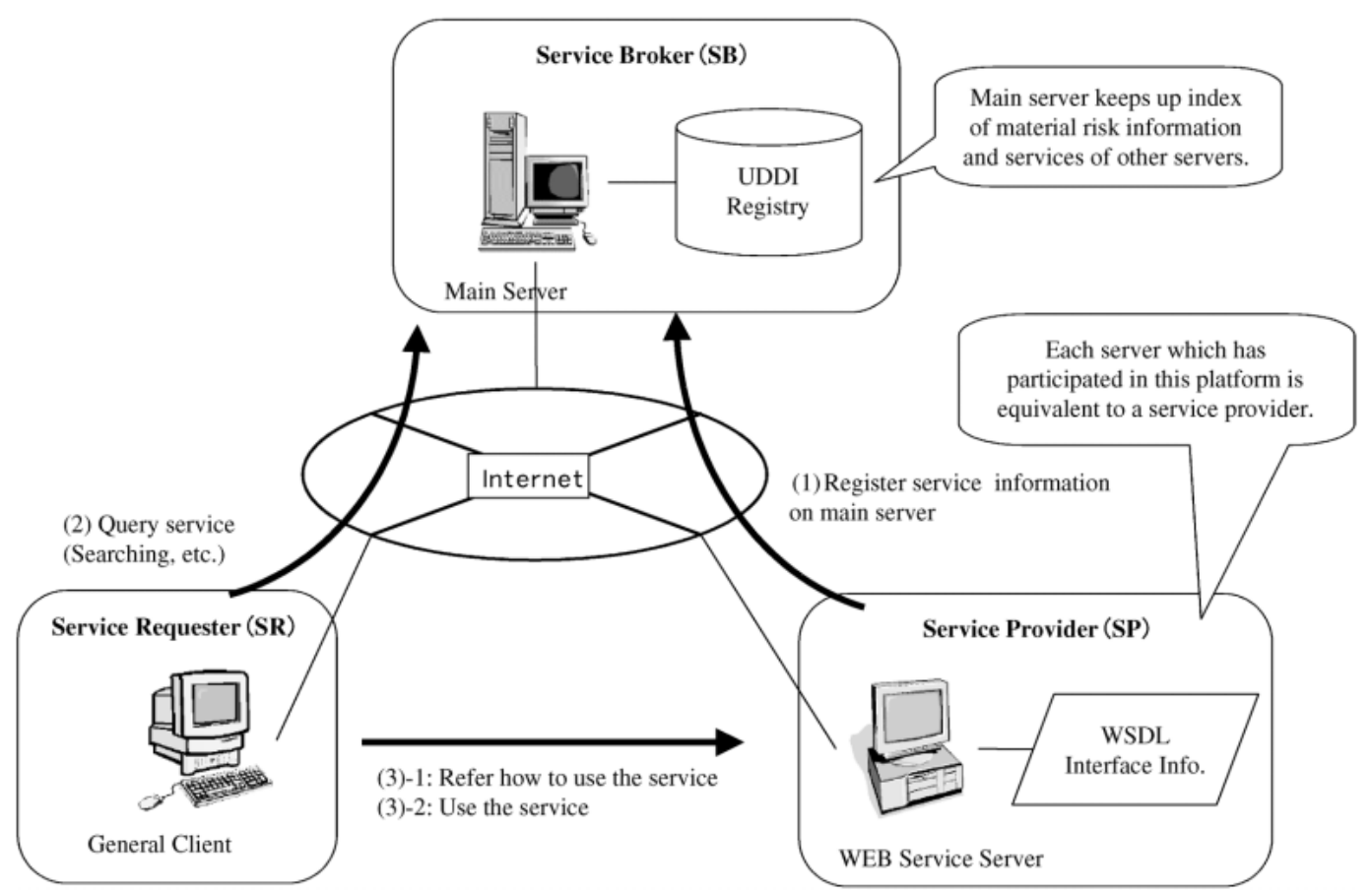

Fig. 2 Basic example of UDDI \& WSDL. 
WSDLを用いたサービス提供および利用例である.

\section{(2) UDDI と WSDL の応用的な利用例}

UDDI とWSDL の応用的な利用例を Fig. 3 に示す. Fig. 3 においても SB と SP および SR の関係は基本的な利用例 と同様である. 但し，二つの $\mathrm{SP}(\mathrm{A}, \mathrm{B})$ が示されている.

第一ステップとして基本的なサービスを行っている SP が SOAP を利用して SB にサービス内容を登録する。この情報 が UDDI として管理される. 次に第二ステップとして，新 たなサービスを提供したいと考えた $\mathrm{SP}(\mathrm{B})$ が $\mathrm{SB}$ (メイン サーバー)にアクセスして既存のサービスを検索する. $\mathrm{SP}(\mathrm{A})$ が提供するサービス内容抢よびそのインターフェイ スをUDDI と WSDL 情報から知ることができるので，SP (A)のサービスも活用した応用サービスを提供するべく, サービスを構築する．これが第三ステップである．第四ステ ップとして $\mathrm{SP}(\mathrm{B})$ も構築されたサービスをやはり UDDI と して SB に登録する．第五ステップとしてユーザーがメイン サーバーからなんらかの材料リスク情報を取得しようとして アクセスし， SP (B)の応用的なサービス提供を知る. 第六ス テップとしてユーザーは SP $(\mathrm{B})$ が提供するサービスを利用 する.この際， SP (B) は SP $(\mathrm{A})$ の提供するサービスも利用 して提供していることになる.

このようなサービスの例としては，複数の材料物性データ ベースを横断して検索し，情報を提供するようなものが相当 する.

\section{3 材料リスク評価情報の提示機能}

ここでは，基本的な材料データのバラツキにともなう機能 損失の発生に関する情報支援を中心にした評価情報の提示機 能を示す。ここで言うバラツキとは金属材料を想定してお
り，「材料の化学成分の偏析」「熱処理条件の不均一」「加工 方法の差異」等に由来する，引張強さや疲労寿命，クリープ 強度などの分布である。これらの情報は，材料リスクの発生 確率を定量または定性的に考慮する際に有益な情報となる.

材料リスク情報提示・評価機能を包含したフロー図を Fig. 4 に示す.フローは大きく分けて三つの評価ステップま たは評価支援機能により構成される.

第一ステップは，本システムが提供する材料 DB（分散さ れているインターネット上の DB を含む)やユーザー自身が 持っている材料データをシステム内で統合または分離して材 料のバラツキ状態の把握を支援する機能である．先述した UDDI やWSDL の定義に従ってこれらの DB サービスが構 築されれば，分散されていることの差異のみでデータの読み 込みに大きな問題は生じない。読み込んだデータは同一のグ ラフや帳票上に情報ルーツがわかるように提示し，各種の補 間や外挿機能を提供し，評価に用いる材料特性の分布情報を 提供することを示している.

第二ステップは，第一ステップの結果を踏まえて，現在想 定している材料データ(および使用条件)において各種規格情 報 (許容応力規格等) や寿命予測手法 (クリープ寿命予測等) と 組み合わせて，どのような危険度があるかを示すものであ る.ここで言う危険度とは想定荷重と許容強度との関係提示 や破損確率情報である.

第三のステップは，使用条件のバラッキ等も含めた破壊確 率に相当する情報を提示するステップである．ユーザーの使 用環境において，外力の分布等を考慮して評価する WEB サービスが提供されれば，材料特性の分布曲線と重ねること で，破壊確率を算出することができる ${ }^{8)}$. また，財団法人電 力中央研究所において本プロジェクトの一環として開発され

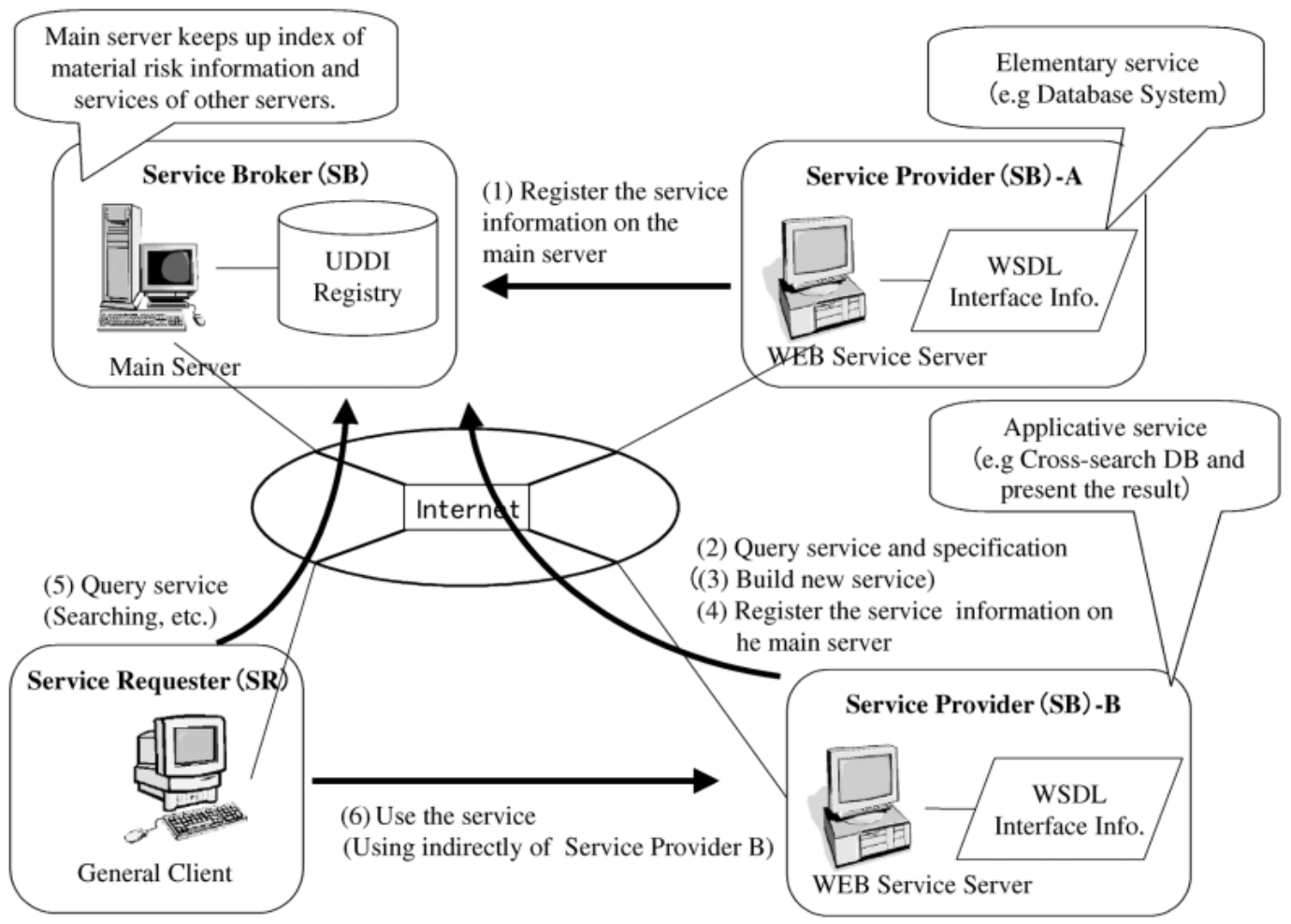

Fig. 3 Applicative example of UDDI \& WSDL. 


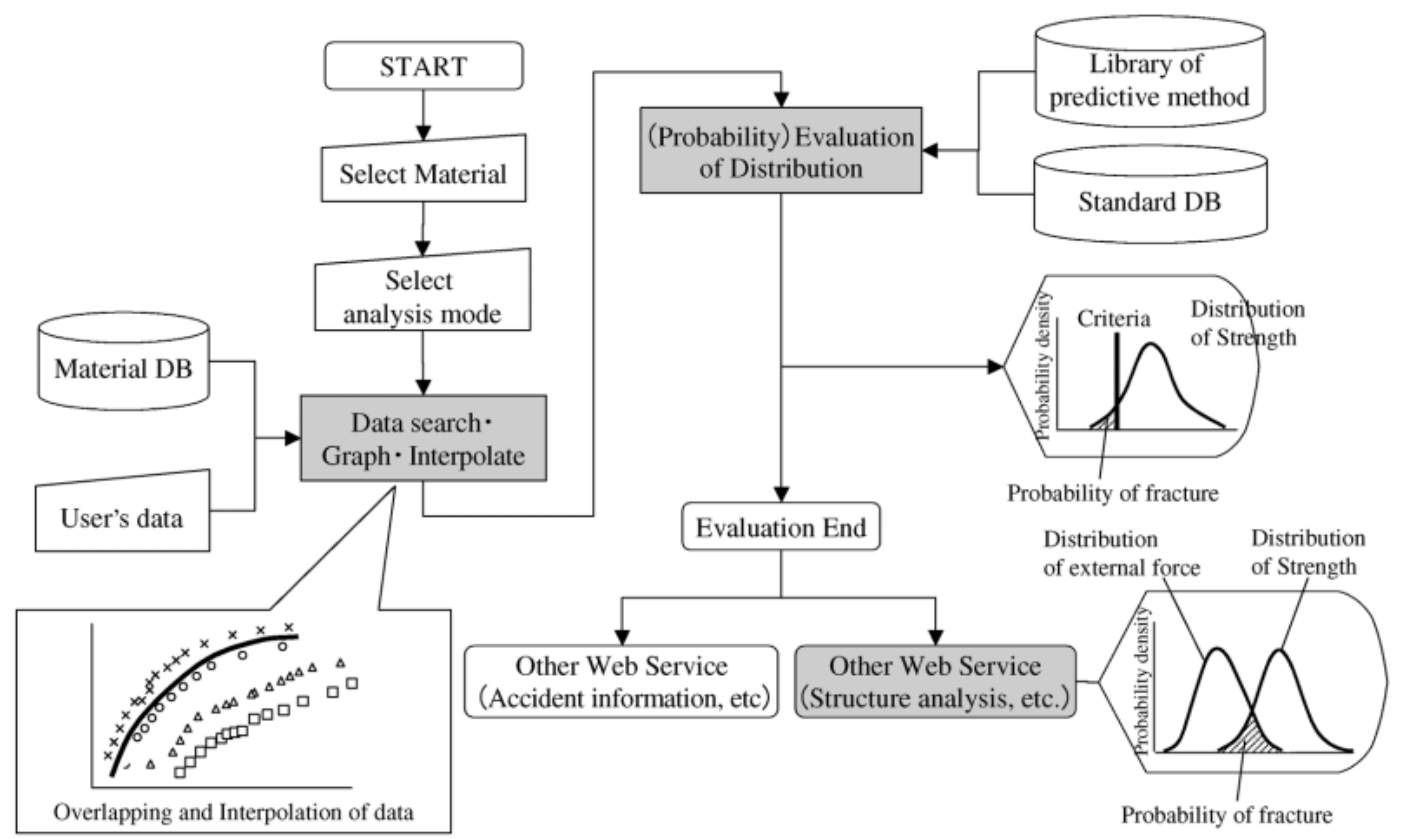

Fig. 4 Flow of presentation and evaluation function of material risk information.

る「設備診断支援システム」の FEM 構造解析を利用するこ とで，より詳細な破壊状態(または健全性)を評価することが できると考える ${ }^{9)}$.

ここでは，材料データのバラツキに基づく材料リスクの発 生確率の考慮を支援する機能について示した。しかし実際に 材料リスクを考慮する場合は材料の機能損失にともなう影響 度も考慮する必要がある，影響度については，本プラットフ オームの機能の一つである事故事例情報をもとに, どのよう な規模の影響が発生し得るかをユーザーに知識として提供し ていくことを検討している.

\section{5. ま と め}

2001 年度より開始された，材料リスク情報プラットフ ォームシステム開発における材料リスク情報の考え方とプラ ットフォームの意味を説明した．本システムでは，材料リス ク情報として「材料の基礎データ」「材料の寿命試験データ」 「材料に起因する事故情報」「規格・基準の情報」「各種評価 関連情報」「その他のリスク情報」の 6 分類を作り，「材料 リスク情報に関するポータル機能」「材料リスク情報と WEB サービスの追加機能」「材料リスク評価情報の提示機 能」を有することを想定している．これらの機能により，拡 張可能な分散システムになるとともに，今までユーザーが独 自に情報収集する必要があった材料リスクに関する情報を比 較的容易に提供できる環境を実現できると考える.

現在は, 本報告に示した仕様のもとにシステム開発を行っ ているがいくつかの課題がある．本システムに関する主な課 題を最後に整理する.

\section{1 材料リスクにおける課題}

本システムの特徵として材料を中心においたリスクの体系 が前提にある。この体系では，材料の用途により目的とする
機能を損失することがリスクであると捉えている.しかし， 一般的なリスクの体系に打いては，材料を原因または原因の 一つとするリスクにおいて，当初想定していた機能損失以外 に抢いても結果的な被害が発生する場合がある。例えば，機 器の保守交換等で当初と異なる材質の備品を設置したために 異材接触の問題が生じて, 想定外の腐食が起るようなことで ある. また, 設計時に想定していなかった雨水の浸透などに よって生じる破壞である。これらは材料が使われる用途だけ を考えていただけでは想定されない被害シナリオである. 現 在これらの材料起因の一般的なリスク情報は, 事故事例とし て示されたものや関連情報として提供されたものはシステム に取込むことが可能である.しかし，これらのリスクシナリ オ自体を評価する枠組みを本システムは有していない。この ような知見情報を今後プラットフォーム全体で蓄えて行くこ とも課題と考える.

\section{2 メ夕情報記述および登録の課題}

本システムでは, 拡張性と標準を意識して, WEB サービ スの次世代標準となり得る UDDI とWSDL に準拠したシス テム開発をコンセプトにしている. 現在は本報告でも言及し た UDDI, WSDL, SOAP 等の仕様が拡張されている段階で ある10)。この仕様の推移は, システム開発の見極めを多少 難しくしている.

さらに, UDDI に打ける登録データ内容の限界やWSDL に抢けるメタ情報の記述に拈いて詳細な API まで定義でき る訳ではないので, この部分の詳細仕様においてメインサー バー側と将来を鑑みた提供サーバー側でいかに矛盾ないよう に開発を進めるかが大きな課題といえる.

また, 新規サービスが提供される際, UDDI 情報を自動登 録することも技術的には可能であるが，材料リスク情報と無 関係なサービスが登録されると意味が無い. 従って, いかに 有益な情報が WEB サービスとして提供されるかを判断する 
尺度や機能が運用にあたっては必要となると考える。

\section{文献}

1) H. Kobayashi: Proc. of the 46th, 47th Shiraishi Kinen Kouza (2001) pp. 33-48.

2) M. Higuchi: Journal of Japan Society for Safety Engineering $\mathbf{3 9}$, No. 3 (2000) 150-158.

3) T. Shuto, H. Tsuchiya and Y. Oyatsu: Proc. of The 22nd Japan Symposium on Thermophysical Properties (2001) pp. 335-337.

4) K. Yagi: Proc. of the 50th Annual Conference of the Society of Material Science, Japan (2001) pp. 229-230.

5) K. Ono and K. Maruyama: NII Journal No. 3 Nov. (2001) pp. 1-
5.

6) Lagoze, Carl, C. A. Lynch and R. Daniel Jr.: Cornell Computer Science Technical Report TR96-1593 (1996) pp. 1-26.

7) T. Shimamoto, A. Kakigi, S. Nishimoto, K. Noma, S. Nogami, R. Kamekura, K. Matsumoto and N. Fukuhara: Web Service Kanzen Kouchiku Guide, (Nikkei BP, 2001) pp. 104-108.

8) T. Sakai, K. Tokaji, N. Hasegawa, M. Nakajima, H. Nakayama, T. Torii, Y. Kimura, Z. Maekawa, T. Tanimoto and T. Hoshide: Zairyou Kyoudo no Toukeiteki Seisitsu, (Youkendou, 1992) pp. $1-5$.

9) T. Fujioka, T. Ogata, T. Yoshida, D. Kato and Y. Matsumura: Proc. of The 14th Computational Engineering Conference (2001) pp. 353-354.

10) Y. Yonemochi: Web Service Perfect Guide, (Shoueisha, 2002) pp. 83-96. 